\title{
Interaksi Simbolik dan Ekologi Media Dalam Proses Keterlibatan Sebagai Roleplayer
}

\author{
Meydhita Stevanny, Muhammad Adi Pribadi \\ meydhitas97@gmail.com,adip@fikom.untar.ac.id \\ Fakultas Ilmu Komunikasi Universitas Tarumanagara
}

\begin{abstract}
Roleplayer is a game that played by acting as a certain character. Also in roleplaying there is a use of language, symbols and words to interact with each other and human dependence on the use of media when playing is one of the interests for researchers. This study aims to determine the role of symbolic interaction and media ecology in roleplaying games by focusing on out of character on twitter, the theory used in this study is symbolic interaction theory, media ecology theory. The research approach used is qualitative description with ethnographic methods. Researchers collected data by conducting participant observation, indepth interviews with several roleplayer players out of character and library studies. The conclusion of this study is that individuals are involved in several stages in the process of involvement of someone roleplayer, namely: introduction, finding information, determining character, and starting to play. In roleplayer there is the use of language, certain words and symbols, expectations (Pygmalion effect), and rules in play.
\end{abstract}

Keywords: ethnography, media ecology, roleplayer, symbolic interaction.

\begin{abstract}
Abstrak
Roleplayer adalah permainan yang dimainkan dengan berperan sebagai karakter tertentu. Permainan roleplayer menggunakan bahasa, simbol serta kata-kata untuk saling berinteraksi serta ketergantungan manusia dalam penggunaan media ketika bermain. Penelitian ini bertujuan untuk mengetahui peran interaksi simbolik dan ekologi media dalam permainan roleplayer dengan berfokus pada out of character di media sosial Twitter. Penelitian ini menggunakan teori interaksi simbolik dan ekologi media. Pendekatan penelitian yang digunakan adalah kualitatif deskripsi dengan metode etnografi. Peneliti mengumpulkan data dengan melakukan observasi partisipan, wawancara mendalam dengan beberapa pemain roleplayer out of character dan studi kepustakaan. Kesimpulan dari penelitian ini adalah individu terlibat dalam beberapa tahapan dalam proses keterlibatan seseorang permainan roleplayer yaitu: perkenalan, mencari informasi, menentukan karakter, dan mulai bermain. Di dalam roleplayer terdapat penggunaan bahasa, kata-kata serta simbol-simbol tertentu, harapan-harapan (pygmalion effect), dan peraturan-peraturan dalam bermain.
\end{abstract}

Kata Kunci: ekologi media, etnografi, interaksi simbolik, roleplayer

\section{Pendahuluan}

Perkembangan teknologi yang semakin maju membuat kehidupan manusia semakin terbantu. Dengan majunya teknologi, manusia dapat melakukan semua kegiatannya dengan cepat dan mudah. Kebutuhan akan informasi, hiburan, pendidikan, pekerjaan, akses internet dan komunikasi semuanya dapat dilakukan dalam satu genggaman. Media merupakan salah satu teknologi yang digunakan manusia untuk mendapatkan informasi baik dari dalam maupun luar negeri. Menurut 
Thomas L. Friedman (2007), the world is flat artinya bahwa dunia semakin rata dan setiap orang bisa mengakses apapun dari sumber manapun. Menurut Richard Hunter (2002) dengan world without secrets, kehadiran media baru (new media/cybermedia) menjadikan informasi sebagai sesuatu yang mudah dicari dan terbuka (Nasrullah, 2017).

Media tradisional saat ini telah tersaingi oleh media baru. Penonton dapat menikmati hiburan yang disiarkan oleh TV di YouTube. Munculnya media baru ini lebih memberikan kebebasan pada penonton untuk mengakses kapan dan dimana saja, sumber dan waktu yang tidak terbatas menyebabkan media baru lebih banyak digemari oleh masyarakat. Media sosial merupakan sebuah wadah di internet yang dapat diakses oleh semua orang untuk dapat saling berinteraksi, berbagi informasi, membagikan foto atau video, bekerja dan membentuk sebuah hubungan. Dengan adanya media sosial juga memudahkan penyebaran informasi antar sesama, selain itu juga mudah untuk menghubungi satu sama lain (Nasrullah, 2017).

Twitter merupakan salah satu media sosial yang banyak digunakan oleh masyarakat Indonesia. Twitter merupakan jejaring media sosial dengan logo burung berwarna putih dengan latar biru yang memungkinkan penggunanya untuk berkirim dan membaca pesan yang tidak lebih dari 280 karakter. Sebelumnya, twitter membatasi tweet dengan 140 karakter tetapi pada tanggal 7 November 2017 ditambah menjadi 260 karakter. Pesan yang dikirimkan dapat berupa tulisan, foto, video maupun gif atau gambar bergerak yang disebut dengan tweet. (https://www.nesabamedia.com/pengertian-twitter/)

Semua orang dari seluruh penjuru dunia yang memiliki akses internet dapat bertemu dan berinteraksi melalui twitter. Dengan twitter, pengguna dapat mendapatkan teman, mencari pasangan, membentuk sebuah komunitas, berjualan, hingga memainkan sebuah permainan. Semua orang tentunya suka bermain game, baik itu game tembak-tembakan, menari, balapan, memasak, berdandan, hingga roleplaying. Roleplayer atau roleplaying adalah sebuah dunia permainan yang dimainkan dengan memparodikan atau memerankan sebuah karakter. Karakter tersebut dapat berupa siapa saja, biasanya artis atau tokoh terkenal yang dijadikan karakter tetapi bisa juga karakter anime atau kartun. Roleplayer berguna untuk mempromosikan artis atau tokoh terkenal yang disukai agar dapat dikenal dengan para pengguna lainnya. Dengan adanya roleplayer dari seorang artis baru maka hal tersebut dapat membantu awareness terhadap artis tersebut.

Dalam memainkan roleplayer tentunya memiliki efek terhadap para pemainnya salah satunya yaitu ketergantungan pada penggunaan media terutama gadget. Selain itu, dalam bermain roleplayer tentunya mengharuskan para penggunanya berinteraksi. Interaksi tentu memerlukan simbol-simbol yang saling dimengerti oleh satu sama lain. Maka dari itu, penulis tertarik untuk membahas lebih dalam mengenai peran interaksi simbolik dan ekologi media dalam proses keterlibatan seseorang dalam roleplayer.

\section{Metode Penelitian}

Pendekatan penelitian yang digunakan penulis dalam meneliti pembentukan identitas diri pada permainan roleplayer dalam media sosial Twitter adalah pendekatan kualitatif deskriptif. Metode kualitatif pada awalnya muncul karena terjadi perubahan paradigma dalam memandang suatu realitas atau fenomena atau gejala. Metode kualitatif adalah metode penelitian yang digunakan untuk meneliti pada kondisi obyek 
yang alamiah (sebagai lawannya dari eksperimen) dimana peneliti adalah sebagai instrumen kunci. Metode ini digunakan untuk mendapatkan data yang mendalam, data tersebut mengandung makna. Makna adalah data yang sebenarnya, maka data yang sebenarnya merupakan nilai dari data yang tampak (Sugiyono, 2016).

Metode penelitian yang digunakan adalah etnografi. Pengertian etnografi menurut Kuswarno (2008) yaitu pengkajian peranan bahasa dalam perilaku komunikasi suatu masyarakat, yaitu cara-cara bagaimana Bahasa dipergunakan dalam masyarakat yang berbeda-beda kebudayaannya. Sehingga dalam metode penelitian etnografi, peneliti ikut serta dalam kelompok masyarakat tertentu agar dalam melihat dan terlibat secara langsung terhadap proses komunikasi yang terjadi. Dengan menggunakan metode penelitian etnografi, peneliti juga dapat menganalisis dan menjelaskan perilaku komunikasi dari suatu kelompok sosial, sehingga hal tersebut dapat memudahkan peneliti. Berdasarkan dasar pemikiran etnografi komunikasi, bahwa saluran komunikasi yang berbeda akan mengakibatkan perbedaan struktur berbicara dan kebudayaan suatu kelompok masyarakat. Maka para pemain roleplayer di Twitter yang tentunya menggunakan bahasa-bahasa tertentu untuk berkomunikasi akan memiliki struktur Bahasa dan perilaku komunikasi tersendiri. Hal tersebut yang akan ditemukan dan dikaji lebih jauh oleh etnografi komunikasi.

Metode pengumpulan data yang dilakukan untuk mengumpulkan data dilakukan dengan observasi partisipan, wawancara mendalam dan analisis dokumen. Humphrey dalam Phenomenological Research Methods memberikan contoh teknik keabsahan data dengan mengirimkan hasil penelitian kepada masing-masing informan dan meminta mereka untuk mengoreksi atau memberikan masukan (Kuswarno, 2008). Sugiyono (2017) juga mengatakan bahwa kriteria yang digunakan dalam menilai kualitas suatu penelitian adalah dengan melakukan konfirmasi ulang atau member check kepada subyek mengenai data hasil analisis yang telah dicatat oleh peneliti terlebih dahulu. Tujuannya untuk mengetahui seberapa jauh data yang diperoleh sesuai dengan apa yang diberikan oleh informan.

\section{Hasil Temuan dan Diskusi}

Berdasarkan observasi serta wawancara yang dilakukan peneliti, terdapat tahapan seseorang atau individu terlibat dalam permainan roleplayer, yang dimulai dari: perkenalan, mencari informasi, menentukan karakter, dan mulai bermain. Pada tahap awal sebelum bermain roleplayer, adanya ajakan atau harapan dari orang lain (Pygmalion Effect) kepada individu maka individu akan tertarik untuk mencari informasi dan mencoba untuk bermain. Harapan dari orang lain dapat mempengaruhi keputusan seseorang untuk terlibat dalam permainan. Seperti yang disebutkan oleh Mead, bahwa melalui pengambilan peran atau role taking dapat membantu seseorang untuk merasakan apa yang dirasakan oleh orang lain serta menumbuhkan rasa empati. Dengan bermain roleplayer, ketika seseorang memerankan sebuah karakter maka orang tersebut merasakan seakan-akan dirinya adalah karakter tersebut. Hal tersebut dapat membuat seseorang merasakan bagaimana rasanya menjadi orang lain sehingga menjadi lebih mudah untuk berinteraksi. Dengan penggunaan kata-kata atau simbolsimbol yang merupakan simbol signifikansi (significant symbol) serta penggunaan bahasa Indonesia yang digunakan untuk berkomunikasi dan berinteraksi melalui tahap perkenalan ini. 
Setelah mengenal dan adanya ajakan dari orang lain kepada individu untuk bermain, pada tahap kedua individu mulai mencari informasi mengenai roleplayer. Roleplayer merupakan permainan yang dimainkan dengan berperan sebagai orang lain, maka individu akan mencari informasi mengenai karakter yang akan diperankan. Informasi yang dicari sangat berguna untuk mendalami karakter peran ketika bermain sehingga dapat memudahkan untuk berinteraksi satu sama lain. Dalam pencarian informasi, peran media sangat membantu untuk memudahkan dalam mencari informasi dengan lengkap dan cepat. Media yang digunakan juga disesuaikan dengan kebutuhan, mulai dari data diri hingga gambar yang akan digunakan selama bermain roleplayer.

Selama proses pencarian informasi mengenai roleplayer dan pencarian informasi karakter yang akan dimainkan memperlihatkan bahwa kehidupan manusia tidak dapat lepas dari media, karena seperti yang dikatakan McLuhan bahwa media membantu kehidupan manusia dalam memperoleh informasi. McLuhan juga mengatakan bahwa media memiliki pengaruh yang kuat dalam mempengaruhi persepsi yang diterima oleh manusia. Setelah mendapatkan informasi mengenai karakter melalui media seperti Google, fanbase hingga Youtube. Semua informasi yang didapatkan melalui media tersebut mempengaruhi tindakan seseorang dalam memerankan karakter pada permainan roleplayer. Dalam pencarian informasi yang dilakukan pada tahap kedua tidak terlepas dari penggunaan significant symbol. Seperti definisi yang Mead katakan mengenai significant symbol sebagai simbol yang maknanya sudah disepakati oleh bersama. Jika tidak ada kesamaan makna maka informasi yang didapat bisa saja berbeda atau salah.

Tahap ketiga setelah individu mendapatkan informasi lebih banyak mengenai roleplayer serta karakter-karakter yang nantinya akan diperankan, berikutnya adalah menentukan media yang akan digunakan untuk bermain. Sebuah game atau permainan tentunya membutuhkan media sebagai sarana pendukungnya untuk dapat dimainkan. Pada permainan roleplayer, media yang digunakan sebagai wadah untuk bermain berupa media sosial. Media sosial yang dipilih disesuaikan dengan keinginan orang yang akan bermain. Para informan memilih Twitter sebagai media yang mewadahi permainan roleplayer. Sejak awal bermain mereka mengenal Twitter sebagai media yang pada saat itu sedang banyak digunakan untuk bermain roleplayer. Fitur Twitter yang nyaman dan mudah untuk bersosialisasi dalam mencari teman menjadi salah satu alasan penggunaan Twitter dalam bermain roleplayer. Pada saat itu penggunaan media sosial Twitter sedang banyak digunakan dibandingkan media sosial lainnya.

Jaringan merupakan salah satu karakteristik media sosial yang disebutkan oleh Nasrullah, jaringan menyambungkan para penggunanya yang kemudian membentuk komunitas. Nasrullah juga menyebutkan bahwa komunitas virtual berisikan anggota yang membangun relasi antar sesamanya sehingga tidak ada individu yang sendiri. Secara tidak langsung, roleplayer merupakan komunitas virtual yang berisikan anggota-anggota yang memiliki kesamaan yang sama dan saling terhubung satu sama lain. Karakteristik tersebut membuat media sosial Twitter sebagai wadah untuk bermain roleplayer.

Setelah individu mencari informasi mengenai karakter yang akan diperankan dan media yang akan digunakan untuk bermain maka selanjutnya adalah penentuan karakter. Karakter tersebut dapat disesuaikan dengan keinginan individu untuk berperan sebagai siapa. Pada umumnya karakter yang diperankan adalah artis, tokoh maupun idola yang disukai. Adanya rasa kesukaan dan nyaman dengan karakter menjadi salah satu alasan untuk memerankan karakter pilihannya. Ketika sudah suka 
dan nyaman maka akan mudah untuk mengetahui kepribadian dari karakter tersebut. Hal tersebut mempermudah individu dalam menentukan karakter yang akan dipilih untuk diperankan.

Pada tahap menentukan karakter, individu mampu memilih dan kemudian menempatkan diri sebagai orang lain. Seperti yang disebutkan Mead mengenai role taking bahwa individu mampu menempatkan diri di posisi orang lain. Hal tersebut sesuai dengan yang dilakukan oleh individu ketika bermain roleplayer. Selain adanya rasa suka dan nyaman, muncul harapan-harapan tertentu ketika memilih untuk memerankan suatu karakter. Seperti harapan bahwa karakter yang akan diperankan dikenal dan dihormati oleh pemain roleplayer lainnya, sebagaimana karakter tersebut dikenal dan dihormati pada kenyataannya. Sama seperti pada tahap perkenalan, terdapat Pygmalion Effect yaitu harapan-harapan dari karakter yang nantinya akan diperankan. Jika pada saat tahap perkenalan harapan yang diberikan berasal dari orang lain kepada individu, pada tahap ini harapan tersebut muncul untuk karakter yang akan diperankan oleh individu. Selama proses menentukan karakter, tentunya muncul berbagai pertimbangan seperti yang disebutkan Mead mengenai bagaimana diri terlihat dari pandangan orang lain (looking-glass self) ketika memerankan suatu karakter. Sehingga saran atau pertimbangan dari orang lain juga mempengaruhi penentuan karakter.

Tahap terakhir, yaitu mulai bermain. Setelah mengenal, mencari informasi, menentukan media yang akan digunakan dan menentukan karakter maka tahap selanjutnya individu dapat mulai bermain. Tahap-tahap sebelumnya yang sudah dilakukan oleh individu merupakan persiapan yang harus dilakukan sebelum mulai bermain roleplayer. Pada tahap terakhir, peneliti melalui observasi partisipan serta wawancara mendalam menemukan adanya bahasa serta simbol tertentu yang digunakan dalam berinteraksi di roleplayer, peraturan-peraturan dalam bermain roleplayer, jenis-jenis roleplayer, serta ketergantungan individu dengan media pada saat bermain roleplayer.

Seperti yang telah dikatakan oleh Mead bahwa pikiran memiliki kemampuan untuk menggunakan significant symbol. Hal tersebut memiliki peran yang penting karena interaksi yang dilakukan dalam roleplayer menggunakan bahasa hingga simbol-simbol tertentu. Selain itu, dapat dilihat bahwa dengan adanya penggunaan bahasa lain selain bahasa Indonesia menunjukkan bahwa media menyatukan seluruh dunia seperti yang dikatakan oleh McLuhan. Peraturan-peraturan pada roleplayer yang telah ditetapkan apabila tidak ditaati dapat menimbulkan efek negatif kepada pemain. Bila dilanggar dapat berakibat buruk kepada pemainnya, salah satu dampak buruknya adalah menjadi bahan pembicaraan negatif oleh orang lain. Seperti yang telah disebutkan oleh Joel M. Charon (dalam Pribadi, 2018) mengenai generalized others pada masyarakat.

Selama melakukan observasi partisipan dalam permainan roleplayer, peneliti melihat dengan adanya penggunaan bahasa, simbol atau kata tertentu di roleplayer, pemilihan karakter hingga peraturan dalam bermain. Ini membentuk sesuatu yang baru seperti pengelompokkan kategori roleplayer. Kategori tersebut membedakan jenis roleplayer yang dimainkan, seperti OOC (Out Of Character), Less OOC (Out Of Character), OCRP (Original Character Roleplayer), hingga AURP (Augmented Roleplayer). Jenis-jenis yang dimainkan dalam roleplayer disesuaikan dan dipilih sendiri oleh pemain. Hal tersebut terbentuk melalui sisi kreatif dari pada pemain roleplayer, seperti yang terdapat dalam teori interaksi simbolik pada bagian diri. Dalam temuan peneliti, terdapat dalam diri individu di permainan roleplayer ini. 
Seperti yang Mead tegaskan bahwa ini yang kemudian menimbulkan sisi kreatif dari diri seperti adanya penggunaan simbol slash (/) dan atau simbol bintang $\left(^{*}\right)$ untuk digunakan dalam berimajinasi di roleplayer. Selain itu juga terdapat pembagian jenisjenis roleplayer seperti OOC, Less OOC, AURP hingga OCRP.

Selama bermain roleplayer, para individu cenderung akan langsung membuka notifikasi yang didapatkan dari Twitter. Mereka menemukan dunia yang baru sehingga sangat senang dan antusias dalam bermain roleplayer. Dalam bermain roleplayer, ratarata individu menghabiskan waktu hampir seharian dikarenakan aplikasi Twitter terdapat di handphone dan tidak ada jam yang pasti ketika bermain. Ketika bermain roleplayer terdapat juga hal-hal yang kemudian mengubah pandangan individu terhadap karakter yang dimainkan oleh orang lain. Adanya perbedaan pada karakter yang dimainkan oleh orang lain merupakan salah satu penyebabnya. Selain itu juga dikarenakan adanya perubahan pada sikap teman ketika berinteraksi di roleplayer. Hal-hal tersebut yang kemudian membuat berubahnya pandangan terhadap karakter asli yang diperankan oleh orang lain tersebut.

Dikarenakan individu yang memainkan karakternya dengan tidak sesuai maka muncul pemikiran atau pandangan tertentu terhadap karakter aslinya. Hal tersebut dapat membuat individu menjadi tidak suka dengan artis yang diperankan walaupun padahal hal tersebut bukan tindakan dari artis aslinya melainkan dari individu yang memainkan peran artis tersebut. Seperti yang dinyatakan oleh McLuhan mengenai media mempengaruhi persepsi manusia. Ketika melakukan observasi di dalam permainan roleplayer, peneliti menemukan adanya pemilik akun yang berasal dari luar Indonesia. Hal tersebut peneliti ketahui dari penggunaan bahasa selain bahasa inggris dan Bahasa Indonesia. Hal tersebut membuktikan bahwa media menyatukan seluruh dunia, melalui media sosial twitter setiap penggunanya dapat bertemu dengan pengguna lainnya baik yang berasal dari dalam maupun luar negeri. Penggunaan media sosial twitter sebagai tempat bermain roleplayer tentunya tidak lepas dari karakteristiknya. Peneliti selama melakukan observasi menemukan adanya karakteristik media sosial pada twitter sebagai aplikasi social networking dan media sharing. Peneliti juga menemukan bahwa para pemain roleplayer ini secara tidak langsung merupakan komunitas virtual yang memiliki tujuan yang sama dan saling berinteraksi di dalam satu wadah.

\section{Simpulan}

Terdapat tahapan individu terlibat dalam permainan roleplayer dimulai dari: perkenalan, mencari informasi, menentukan karakter, dan mulai bermain. Terdapat simbol, kata-kata hingga bahasa tertentu yang hanya dimengerti dan digunakan di dalam permainan roleplayer pada media sosial Twitter. Selain itu juga terdapat harapan-harapan serta pertimbangan dalam memilih karakter yang akan diperankan dalam roleplayer. Individu sebagai pemilik akun roleplayer juga menempatkan dirinya sebagai orang lain ketika bermain. Terdapat peraturan-peraturan yang harus ditaati dalam permainan roleplayer, yang tentunya memiliki akibat tersendiri bagi individu jika melanggarnya. Lalu, juga muncul hal-hal baru dalam roleplayer seperti pembentukan jenis-jenis roleplayer yang muncul akibat dari kreativitas yang muncul dalam diri selama bermain roleplayer. Hal tersebut sesuai dengan pengertian dari teori interaksi simbolik. 
Dalam permainan roleplayer, informan tidak lepas dari media. Terutama ketika bermain roleplayer, pemain tentunya harus selalu membuka media sosial twitter agar tetap dapat bermain. Hal tersebut menyebabkan manusia bergantung kepada media, media melingkupi dunia manusia sehingga menyebabkan manusia kebergantungan dengan media. Dalam mencari informasi mengenai karakter juga dilakukan di media twitter itu sendiri, sehingga media sangat berpengaruh. Lalu pada permainan roleplayer di twitter juga dapat mengubah pandangan seseorang terhadap karakter yang dimainkan oleh sesama pemain. Lalu dengan adanya penggunaan bahasa inggris juga menunjukkan adanya pemilik akun roleplayer yang berasal dari luar negeri, tidak hanya dari Indonesia. Dengan menggunakan media sosial Twitter dalam permainan roleplayer dapat membantu individu berinteraksi antar sesama pemainnya baik dari dalam maupun luar negeri.

Terbentuknya jaringan sosial antar para pengguna twitter yang tidak saling mengenal satu sama lain namun dapat menjadi kenal di dalam permainan roleplayer ini. Adanya penyebaran informasi yang berupa kata-kata, foto hingga video serta interaksi yang terjadi antar setiap pemain roleplayer hingga terbentuknya komunitas virtual memperlihatkan karakteristik serta budaya populer yang terdapat di dalam media sosial twitter. Terutama fan culture, sebab peneliti menemukan bahwa roleplayer terbentuk karena adanya rasa suka terhadap idola maupun artis sehingga mendorong seseorang untuk menjadi seperti sang idola.

\section{Ucapan Terima Kasih}

Terima kasih kepada Fakultas Ilmu Komunikasi Universitas Tarumanagara serta para narasumber yang telah bersedia untuk meluangkan waktunya dan berpartisipasi dalam penelitian ini sehingga penelitian ini dapat berjalan dengan lancar dan pihak-pihak lainnya yang sudah banyak membantu dalam penelitian ini.

\section{Daftar Pustaka}

Hannani, Nabilah. (2019). Pengertian Twitter Beserta Sejarah dan Manfaat Twitter yang Dibahas secara Lengkap. Agustus 25, 2019. https://www.nesabamedia.com/pengertian-twitter/

Kuswarno, Engkus. (2008). Etnografi Komunikasi Pengantar dan Contoh Penelitiannya. Bandung: Widya Padjadjaran.

Nasrullah, Rulli. (2017). Media Sosial Perspektif Komunikasi, Budaya, dan Sosioteknologi. Bandung: Simbiosa Rekatama Media.

Pribadi, Muhammad Adi., Suganda, Dadang., Venus, Anter., \& Susanto, Eko Harry. (2018). Dinamika Perusahaan Periklanan Indonesia: Studi Kasus Komunikasi dan Budaya Organisasi Dwi Sapta IMC dan Fortune Indonesia. Disertasi Universitas Padjajaran. Bandung: Universitas Padjajaran.

Sugiyono. (2016). Memahami Penelitian Kuantitatif, Kualitatif, dan R\&D. Bandung: Penerbit Alfabeta.

Sugiyono. (2017). Metode Penelitian Kuantitatif, Kualitatif, dan R\&D. Bandung: Penerbit Alfabeta

West, Richard., \& Turner, Lynn H. (2008). Pengantar Teori Komunikasi, Edisi 3, Analisis dan Aplikasi, Buku 1. Jakarta: Penerbit Salemba Humanika.

West, Richard., \& Turner, Lynn H. (2008). Pengantar Teori Komunikasi, Edisi 3, Analisis dan Aplikasi, Buku 2. Jakarta: Penerbit Salemba Humanika. 